\title{
APPLICATION OF MULTIVARIATE STATISTICAL ANALYSIS FOR BREEDING STRATEGIES OF SPRING SAFFLOWER (Carthamus tinctorius L.)
}

\author{
Arzu KOSE, ${ }^{*}$, Oguz ONDER ${ }^{1}$, Ozlem BILIR ${ }^{2}$, Ferda KOSAR ${ }^{1}$ \\ ${ }^{1}$ Transitional Zone Agricultural Research Institute, Eskisehir, TURKEY \\ ${ }^{2}$ Trakya Agricultural Research Institute, Edirne, TURKEY \\ *Corresponding author: arzukose.tr@gmail.com
}

Received: 19.01 .2018

\begin{abstract}
This study aimed to assess oil yield components and their interrelationships of spring safflower lines and varieties by using different statistical techniques to increase the oil yield in safflower breeding program. Field experiments were conducted at the Transitional Zone Agricultural Research Institute in Eskisehir, Turkey during 2014, 2015 and 2016. Correlation, simple linear regression, stepwise multiple regression, path, principal component and cluster analyze were used to investigate the relationships between oil yield and some components in spring safflower. The results revealed that characters affecting oil yield, which is important to determine selection criteria in plant breeding, vary according to statistical methods. Therefore, to obtain reliable result, it is essential to use multivariate statistical methods for scanning significant characters in studied material. According to the numbers of common characters determined in different statistical analyzes; oil content, seed weight, seed yield and number of head per plant would be important selection criteria for improved oil yield in the breeding material studied. The lines and varieties may be used in hybridization program and their hybrids may yield more transgressive sergeants for these characters for oil yield improvement.
\end{abstract}

Keywords: Characters associations, Spring safflower, Selection criteria, Statistical analysis

\section{INTRODUCTION}

The aim of the breeding researches must be determined carefully in order to achieve success. Generally, safflower breeding program aimed to improve adaptable highyielding safflower cultivars. Determination of the characters that affect seed and oil yield in safflower is very important in genetic improvement of these attributes (Golparvar, 2011a). Yield is complicated quantitative character that results to the actions and interactions of different characters (Tonk et al., 2011). Especially, breeding programs intended to develop high-yielding genotypes, it is essential to know how and to what extent these factors affect yield. Selection is the essential parts of these researches. The achievement of selection connects with the choice of selection criteria for improving yield (Samonte et al., 1998). Yield components do not only directly affect the yield, but also indirectly by affecting other yield components in negative or positive ways (Bidgoli et al., 2006). Different statistical methods are used for these purposes.
Correlation coefficients used to determine relationships between yield and yield components have importance in selecting breeding materials (Afroz et al., 2004; Laei et al., 2012; Zafarnaderi et al., 2013). Regression analysis is used to establish the existence of linear relationship between the independent variables and dependent variable. While simple linear regression is preferred the presence of single independent variable, multiple regression analysis is used more than one independent variable (Khan and Nagvi, 2012). However, stepwise multiple linear regression is a method that is used to anticipate the value of a quantitative variable concerning its relation with one or some other quantitative variables. This relation is such that it is possible to predict other changes using one variable (Hannachi et al., 2013). In additional, path coefficient analysis focused to determine the direct and indirect influence of each of the component characters on seed yield (Khan et al., 2013). Principal component analysis is multivariate statistical techniques that aim to simplification in complex plant data sets (Slavkovic et al., 2004). Cluster analysis is an agglomerative hierarchical method and 
classifies variables into groups and to cluster variables reduction their number (Katar, 2013).

Plant height, number of branch per plant, branch height, number of heads per plant, number of seeds per head, head diameter, seed weight and oil content are the most important characters in spring safflower breeding for increasing seed and oil yield (Patil, 1990; Ozturk, 1994; Omidi, 2000; Camas et al., 2005; Topal et al., 2010; Golkar et al., 2011; Golparvar, 2011a; Karimi et al., 2013; Hussain, 2014). These characters are affected from environmental condition and genotypic differences (Camas and Esendal, 2006; Arslan, 2007).

Therefore, the present study was designed to assess yield components and their interrelationships in the present spring safflower material for efficient selection to increase the oil yield in safflower breeding program.

\section{MATERIALS AND METHODS}

In this study was carried out at the Transitional Zone Agricultural Research Institute, (3945"57' N, 30²4" 5' E) in Eskisehir, Turkey during 2014, 2015 and 2016 under rainfed conditions. Experimental location has typically a steppe climate with temperature differences between day and night and dries in summer, relatively rainy winter. Mean temperatures and total rainfall during experimental period (March - August) in 2014, 2015, 2016 and longterm years' values were $16.6^{\circ} \mathrm{C}$ and $207.2 \mathrm{~mm}, 15.2^{\circ} \mathrm{C}$ and $337.3 \mathrm{~mm}, 16.9^{\circ} \mathrm{C}$ and $172.6 \mathrm{~mm}, 15.1^{\circ} \mathrm{C}$ and $166.9 \mathrm{~mm}$, respectively (Table 1). Soils in the research area had clayey and neutral in reaction. It is poor in organic matter and reach in available potassium and phosphorus content.

Table 1. Some climatic data during the 2014, 2015, 2016 growing seasons and long-term values for the experimental area

\begin{tabular}{|c|c|c|c|c|c|}
\hline \multirow[b]{2}{*}{ Mounts } & \multicolumn{5}{|c|}{ Long Term (1965-2016) } \\
\hline & $\begin{array}{c}\text { Lowest temperature } \\
\left({ }^{\circ} \mathbf{C}\right)\end{array}$ & $\begin{array}{l}\text { Highest temperature } \\
\left({ }^{\circ} \mathrm{C}\right)\end{array}$ & $\begin{array}{c}\text { Mean temperature } \\
\left({ }^{\circ} \mathbf{C}\right)\end{array}$ & $\begin{array}{c}\text { Relative } \\
\text { humidity } \\
(\%)\end{array}$ & $\begin{array}{l}\text { Rainfall } \\
\text { (mm) }\end{array}$ \\
\hline March & -9.1 & 22.1 & 4.8 & 62.2 & 33.6 \\
\hline April & -4.4 & 26.4 & 10.1 & 59.4 & 44.0 \\
\hline May & 0.2 & 29.7 & 14.8 & 56.6 & 44.4 \\
\hline June & 4.1 & 33.4 & 18.5 & 53.5 & 25.1 \\
\hline July & 7.3 & 35.8 & 21.4 & 52.9 & 10.0 \\
\hline August & 6.7 & 34.7 & 21.0 & 52.4 & 9.8 \\
\hline Mean & 0.9 & 30.5 & 15.1 & 56.3 & - \\
\hline Total & - & - & - & - & 166.9 \\
\hline Year & \multicolumn{5}{|c|}{2014} \\
\hline March & -5.9 & 23.0 & 6.2 & 69.0 & 27.1 \\
\hline April & -3.7 & 26.6 & 11.3 & 63.7 & 23.2 \\
\hline May & 6.6 & 28.5 & 16.4 & 63.3 & 53.8 \\
\hline June & 8.9 & 35.4 & 19.9 & 64.1 & 70.5 \\
\hline July & 13.6 & 34.0 & 21.6 & 57.8 & 20.4 \\
\hline August & 15.4 & 36.4 & 24.1 & 58.9 & 12.2 \\
\hline Mean & 5.8 & 30.6 & 16.6 & 62.8 & - \\
\hline Total & - & - & - & - & 207.2 \\
\hline Year & \multicolumn{5}{|c|}{2015} \\
\hline March & -4.7 & 20.3 & 5.7 & 78.6 & 46.0 \\
\hline April & -4.7 & 26.3 & 7.9 & 68.0 & 41.3 \\
\hline May & 2.5 & 30.8 & 15.7 & 64.7 & 61.2 \\
\hline June & 5.8 & 28.2 & 17.2 & 80.7 & 125.3 \\
\hline July & 10.1 & 37.2 & 22.1 & 63.0 & 0 \\
\hline August & 9.6 & 33.9 & 22.7 & 66.3 & 63.5 \\
\hline Mean & 3.1 & 29.4 & 15.2 & 70.2 & - \\
\hline Total & - & - & - & - & 337.3 \\
\hline Year & \multicolumn{5}{|c|}{2016} \\
\hline March & -6.7 & 23.5 & 7.5 & 70.3 & 44.8 \\
\hline April & -1.9 & 28.6 & 12.9 & 64.4 & 23.5 \\
\hline May & 2.8 & 29.9 & 14.2 & 74.3 & 55.3 \\
\hline June & 4.8 & 35.3 & 21.0 & 62.1 & 8.7 \\
\hline July & 14.1 & 38.5 & 22.8 & 58.2 & 8.5 \\
\hline August & 9.6 & 36.5 & 22.8 & 65.8 & 31.8 \\
\hline Mean & 3.7 & 32.1 & 16.9 & 65.8 & \\
\hline Total & - & - & - & - & 172.6 \\
\hline
\end{tabular}


The research plant material comprised of thirty-four spring safflower genotypes included thirty lines and four varieties were sown in plots with 4 rows; plots were $2 \mathrm{~m}$ long, with $45 \mathrm{~cm}$ between rows and $10 \mathrm{~cm}$ between plants within rows in randomized block design with four replications. Seeding was made in the first week of March every year by hand. At seeding, $80 \mathrm{~kg} \mathrm{ha}^{-1}$ nitrogen $(33 \%$ ammonium nitrate) and $60 \mathrm{~kg} \mathrm{ha}^{-1}$ phosphorus (superphosphate) were applied. During growing season weeds were controlled by hand.

The followed data was measured oil yield (OY), seed yield (SY), oil content (OC), plant height (PH), number of branch per plant (NBPP), number of head per plant (NHPP), head diameter (HD) and thousand seed weight (SW). Randomly selected fifteen plants per plot were used to determine yield components. Plants were harvested in August. Data on seed yield were taken from the middle 4 rows of each plot, leaving aside the guard rows on either side of a plot. Oil content of genotype was determined by using soxhlet apparatus. Oil yield was calculated by multiplying oil content and the seed yield of each plot.

Correlation analysis was performed for lines and varieties to analyze the relationships between oil yield and yield characters accurately. Simple linear regression coefficients of oil yield on the different characters studied were analyzed. The stepwise multiple regression analysis was also conducted in for the data provided to test the significance of the independent characters affecting the oil yield. In path analysis; oil yield used as dependent variable, and the other studied characters were use as predictor variables. Beside of these principal component analysis (PCA) was used for understanding the data structure and characters relations. It helps derive a small number of independent linear combinations (principal components) of a set of variables, ways to explore how several variables relate to each other. The platform begins with a standard correlation matrix and gives additional options for correlations and other techniques for looking at several variables. Clustering is a technique of grouping rows together that share similar values across a number of variables.

In this research, Bartlett's test was used to determine the homogeneity of variances for three years. Analysis of variance (ANOVA) was performed and statistically significant differences among the mean values were determined with the least significant difference (LSD) test at the 0.05 level. The data over three years subjected to different statistical analyses, using Jump 5.0.1 and gene stat package programs.

\section{RESULTS AND DISCUSSION}

The results of combined variance analysis showed that, genotypes differed significantly at $\mathrm{p}<0.01$ for all characteristics, indicating significant genetic variability present for these characters among genotypes (Table 2). The presence of variability is important for genetic studies and consequently improvement and selection. Beside of this, significant differences among the years and genotype $\mathrm{x}$ years was found all investigated characteristics. Significant year effects indicated the presence of variability in the environmental variables for three years. The interaction between years and genotypes indicated that differences between genotypes were affected by the growing season.

Table 2. Combined analysis of variance for studied characters over three years

\begin{tabular}{|c|c|c|c|c|c|c|c|c|c|}
\hline & & \multicolumn{8}{|c|}{ Mean squares } \\
\hline & DF & OY & SY & OC & PH & NBPP & NHPP & HD & SW \\
\hline Years & 2 & $39445.7 * *$ & $2914.41 * *$ & $112.472 * *$ & $10827.6 * *$ & $422.451 *$ & $882.005 * *$ & $4.1115 * *$ & $78.0023 *$ \\
\hline Genotypes & 33 & $5266.19 * *$ & $603.925 * *$ & $55.937 * *$ & $320.063 * *$ & $5.85276^{* *}$ & $46.8064 * *$ & $0.16895 * *$ & $21.6975^{* *}$ \\
\hline$Y x G$ & 66 & $2224 * *$ & $207.83 * *$ & $10.1825 * *$ & $131.274 * *$ & $0.9552 * *$ & $8.26812 * *$ & $0.11969 * *$ & $8.317 * *$ \\
\hline
\end{tabular}

Means of oil yield varied between 270.7 and $580.3 \mathrm{~kg}$ $\mathrm{ha}^{-1}$. The seed yield, oil content, plant height, number of branches, number of head, head diameter and for seed weight between 1002.0 and $1881.0 \mathrm{~kg} \mathrm{ha}^{-1}, 24.7$ and 37.4 $\%, 84.5$ and $119.9 \mathrm{~cm}, 4.6$ and 8.5, 12.5 and 23.5, 1.96 and $2.51 \mathrm{~cm}, 35.2$ and $41.1 \mathrm{~g}$, respectively (Table 3 ). According to results, considerable variation was determined among genotypes provided opportunity for selection.

Correlations coefficients determined among the characteristics are presented in Table 4 positive significant relation were found between oil yield and plant height $\left(\mathrm{r}=0.127^{*}\right)$, seed weight $\left(\mathrm{r}=0.298^{* *}\right)$, number of branch per plant $\left(\mathrm{r}=0.326^{* *}\right)$, oil content $\left(\mathrm{r}=0.344^{* *}\right)$, number of head per plant $\left(\mathrm{r}=0.385^{* *}\right)$, seed yield $\left(\mathrm{r}=0.927^{* *}\right)$. According to the results any positive increase in such characters will lead to improve in oil yield. These results implied that oil yield would increase if the genotype having higher plant height, number of branch and head per plant, seed weight, oil content and seed yield in maturity would be selected. Some studies reported that significant and positive relationship with oil or seed yield; number of seed per plant, seed weight, head diameter could safely be used breeding programs (Bidgoli et al., 2006; Mozaffari and Asadi, 2006; Topal et al., 2010; Golparvar, 2011b). Beside of this, Behnam et al. (2011) determined positive and significant relation between number of head per plant with oil yield.

Simple regression coefficients (b) of oil yield on the different characters studied were analyzed, together with their $\mathrm{Sb}$ values. The significance of the coefficients determined was tested by calculating t values (Table 5). All the $b$ values were found positive and highly significant except the $b$ values for plant height over three seasons. The highest regression coefficient was determined at number of branches per plant. Regression coefficient (b values) for 
number of branches per plant, oil content, number of head per plant, seed weight, plant height and seed yield were positively significantly correlated with oil yield indicating that increase in these characters would increase the oil yield. Linear regression of number of branch per plant, oil content, seed yield, number of head per plant, seed weight and plant height leads to increase the oil yield by 1.852 , $1.319,0.289,1.249,1.472$ and 0.116 units, respectively. Presence of highly significant and positive correlation between these characters with oil yield shows that the results of regression analysis are nearly in harmony with correlation results.

Table 3. Mean and least standard deviation (Lsd) values studied characters of thirty-four safflower genotypes over three years

\begin{tabular}{|c|c|c|c|c|c|c|c|c|c|}
\hline $\begin{array}{l}\text { Genotype } \\
\text { number }\end{array}$ & Pedigre & $\begin{array}{c}\text { OY } \\
\left(\mathrm{kg} \mathrm{ha}^{-1}\right)\end{array}$ & $\begin{array}{c}\text { SY } \\
\left(\mathrm{kg} \mathrm{ha}^{-1}\right)\end{array}$ & $\begin{array}{l}\text { OC } \\
(\%)\end{array}$ & $\begin{array}{c}\text { PH } \\
(\mathbf{c m})\end{array}$ & NBPP & NHPP & $\begin{array}{l}\text { HD } \\
(\mathrm{cm})\end{array}$ & $\begin{array}{r}\text { SW } \\
(\mathrm{g})\end{array}$ \\
\hline 1 & 07.2 .1 .1 .1 & 341.0 & 1137.8 & 29.9 & 89.5 & 7.5 & 20.6 & 2.16 & 35.5 \\
\hline 2 & 07.2 .1 .2 .1 & 285.5 & 1016.2 & 28.1 & 85.5 & 7.8 & 21.4 & 2.19 & 36.0 \\
\hline 3 & 07.2 .1 .4 .1 & 336.5 & 1080.1 & 31.2 & 90.8 & 7.3 & 19.5 & 2.11 & 35.3 \\
\hline 4 & 07.2 .2 .1 .1 & 414.1 & 1356.5 & 30.6 & 88.8 & 8.0 & 22.4 & 2.03 & 39.9 \\
\hline 5 & 07.2 .2 .2 .1 & 318.8 & 1080.7 & 29.5 & 97.0 & 8.1 & 21.1 & 1.97 & 36.8 \\
\hline 6 & 07.15 .2 .1 & 498.5 & 1666.9 & 29.9 & 95.9 & 7.8 & 20.9 & 2.10 & 39.4 \\
\hline 7 & 07.15 .2 .2 & 517.5 & 1768.5 & 29.2 & 96.3 & 7.4 & 22.6 & 2.23 & 41.1 \\
\hline 8 & 07.15 .2 .3 & 439.4 & 1431.1 & 30.7 & 91.2 & 7.3 & 21.1 & 2.29 & 40.4 \\
\hline 9 & 07.15 .3 .1 & 511.6 & 1654.3 & 30.8 & 94.0 & 8.1 & 22.5 & 2.17 & 40.1 \\
\hline 10 & 08.6.1.1 & 499.5 & 1777.7 & 28.0 & 90.0 & 8.1 & 21.8 & 2.24 & 38.3 \\
\hline 11 & 08.6.1.2 & 407.3 & 1287.8 & 31.7 & 93.6 & 7.6 & 19.8 & 2.13 & 38.5 \\
\hline 12 & 08.6.7.1 & 443.6 & 1478.6 & 30.0 & 93.7 & 6.8 & 18.6 & 1.96 & 38.9 \\
\hline 13 & 08.6.8.1 & 318.9 & 1002.0 & 31.8 & 98.2 & 7.4 & 20.5 & 2.15 & 38.4 \\
\hline 14 & 08.6.8.2 & 315.3 & 1107.8 & 28.5 & 90.9 & 8.0 & 19.8 & 2.26 & 38.3 \\
\hline 15 & 08.10 .1 .1 & 580.3 & 1881.0 & 31.1 & 84.5 & 8.5 & 23.1 & 2.29 & 41.0 \\
\hline 16 & 08.10 .7 .1 & 367.3 & 1286.5 & 28.9 & 96.8 & 7.2 & 18.4 & 2.10 & 39.1 \\
\hline 17 & 08.13.1.1 & 456.3 & 1537.3 & 30.1 & 91.3 & 6.1 & 17.7 & 2.44 & 40.1 \\
\hline 18 & 08.13 .2 .1 & 483.2 & 1486.2 & 32.8 & 94.7 & 6.7 & 18.2 & 2.10 & 37.4 \\
\hline 19 & 08.14.5.1 & 465.4 & 1524.6 & 30.7 & 96.4 & 7.2 & 18.8 & 2.12 & 37.7 \\
\hline 20 & 08.14 .13 .1 & 450.1 & 1425.1 & 31.6 & 95.7 & 8.3 & 22.2 & 2.18 & 38.3 \\
\hline 21 & 08.14 .13 .2 & 425.6 & 1393.5 & 30.4 & 87.6 & 8.3 & 22.1 & 2.23 & 38.6 \\
\hline 22 & 08.22 .13 .1 & 557.3 & 1826.6 & 30.9 & 94.2 & 8.5 & 23.3 & 2.25 & 38.2 \\
\hline 23 & 5.70 & 449.4 & 1653.1 & 27.3 & 91.6 & 7.2 & 19.5 & 2.14 & 37.4 \\
\hline 24 & 510.1 & 384.2 & 1495.2 & 25.7 & 92.3 & 7.5 & 21.2 & 2.10 & 36.3 \\
\hline 25 & $5.37-5.118$ & 359.0 & 1333.9 & 26.9 & 96.1 & 7.6 & 20.9 & 2.30 & 37.8 \\
\hline 26 & 5.12 .1 & 318.9 & 1308.3 & 24.7 & 92.3 & 6.5 & 19.6 & 2.38 & 36.6 \\
\hline 27 & 1.07 & 346.8 & 1253.9 & 27.7 & 88.4 & 7.2 & 21.0 & 2.22 & 38.1 \\
\hline 28 & $5.154-5.62 .1$ & 405.2 & 1470.0 & 27.3 & 85.5 & 7.4 & 21.5 & 2.33 & 38.2 \\
\hline 29 & $5.154-5.62 .2$ & 405.7 & 1485.9 & 27.7 & 86.8 & 7.5 & 20.8 & 2.27 & 37.6 \\
\hline 30 & $5.75-5.154 .2$ & 495.9 & 1759.1 & 28.5 & 91.0 & 8.4 & 23.5 & 2.28 & 37.0 \\
\hline 31 & $5.122-5.154 .2$ & 344.7 & 1385.6 & 24.7 & 93.9 & 7.6 & 20.7 & 2.39 & 37.4 \\
\hline 32 & Dinçer & 394.3 & 1384.4 & 28.5 & 93.2 & 5.8 & 15.1 & 2.50 & 36.2 \\
\hline 33 & Yenice & 270.7 & 1051.7 & 26.3 & 119.9 & 4.6 & 12.5 & 2.42 & 35.2 \\
\hline 34 & Balcı & 549.4 & 1467.4 & 37.4 & 91.2 & 7.5 & 18.3 & 2.51 & 38.9 \\
\hline Lsd & & 15.8 & 190.5 & 1.4 & 7.7 & 0.6 & 1.6 & 0.12 & 1.4 \\
\hline
\end{tabular}

Table 4. The correlation coefficients among the oil yield and studied characters in safflower

\begin{tabular}{|c|c|c|c|c|c|c|c|c|}
\hline & OY & SY & OC & $\mathbf{P H}$ & NBPP & NHPP & HD & SW \\
\hline $\mathrm{OY}$ & 1 & $0.927 * *$ & $0.344 * *$ & $0.127 *$ & $0.326 * *$ & $0.385 * *$ & $-0,014^{\mathrm{ns}}$ & $0.298 * *$ \\
\hline SY & & 1 & $-0.024^{\mathrm{ns}}$ & $0.108 *$ & $0,330 * *$ & $0.411 * *$ & $0.052^{\mathrm{ns}}$ & $0.220 * *$ \\
\hline $\mathrm{OC}$ & & & 1 & $-0.061^{\mathrm{ns}}$ & $0.046^{\mathrm{ns}}$ & $-0.003^{\mathrm{ns}}$ & $-0.187^{\mathrm{ns}}$ & $0.233 * *$ \\
\hline $\mathrm{PH}$ & & & & 1 & $0.398 * *$ & $0.239 * *$ & $-0.409 * *$ & $-0.064^{\mathrm{ns}}$ \\
\hline NBPP & & & & & 1 & $0.790 * *$ & $-0.452 * *$ & $0.019^{\mathrm{ns}}$ \\
\hline NHPP & & & & & & 1 & $-0.368 * *$ & $0.131 * *$ \\
\hline HD & & & & & & & 1 & $-0.050^{\mathrm{ns}}$ \\
\hline SW & & & & & & & & 1 \\
\hline
\end{tabular}


Table 5. Regression coefficients ( $b$ values) of different component traits on oil yield in safflower along with their standard errors, $t$ value and probability value $(\mathrm{P})$, linear regression equations

\begin{tabular}{ccccccc}
\hline Characters & $\begin{array}{c}\text { Regression } \\
\text { values (b) }\end{array}$ & $\begin{array}{c}\mathbf{R}^{\mathbf{2}} \\
\text { adjusted }\end{array}$ & $\begin{array}{c}\text { Standard error of } \\
\text { coefficients }\end{array}$ & $\begin{array}{c}\mathbf{t}- \\
\text { value }\end{array}$ & $\begin{array}{c}\mathbf{P} \text { - } \\
\text { value }\end{array}$ & $\begin{array}{c}\text { Linear regression } \\
\text { equation }\end{array}$ \\
\hline SY & 0.289 & 0.859 & 0.007 & 43.13 & 0.000 & $\mathrm{OY}=0.67+0.289 \mathrm{SY}$ \\
OC & 1.319 & 0.115 & 0.206 & 6.39 & 0.000 & $\mathrm{OY}=2.92+1.319 \mathrm{OC}$ \\
PH & 0.116 & 0.086 & 0.052 & 2.23 & 0.026 & $\mathrm{OY}=30.89+0.116 \mathrm{PH}$ \\
NBPP & 1.852 & 0.103 & 0.308 & 6.01 & 0.000 & $\mathrm{OY}=27.89+1.852 \mathrm{NBP}$ \\
NHPP & 1.249 & 0.145 & 0.170 & 7.26 & 0.000 & $\mathrm{OY}=16.30+1.249 \mathrm{NHP}$ \\
SW & 1.472 & 0.081 & 0.270 & 5.45 & 0.000 & $\mathrm{OY}=-14.35+1.472 \mathrm{SW}$ \\
\hline
\end{tabular}

Stepwise regression was used to remove effect of noneffective characteristics in regression model on oil yield. In this analysis, oil yield (Y) as dependent variable and other characters as independent variables were considered. Accepted variables and their relative contributions are given in Table 6. Results of stepwise regression indicated that seed yield and oil content with R square of $99.7 \%$, had justified the maximum of oil yield changes. The relative contributions in the total variation of oil yield were $88.1 \%$ for seed yield, $17.9 \%$ oil content. The other characters were not included in the model because of their low relative contributions and the best prediction equation was obtained as follows: $\mathrm{OY}=-40.85+(0.29 \times \mathrm{SY})+(1.39 \times \mathrm{OC}) . \mathrm{A}$ study aimed to determine the best indirect selection criteria for genetic improvement of in spring safflower in terms of oil yield emphasized that seed weight had positive and significant regression coefficient and accounted for $52.0 \%$ of total variation exist in oil yield (Karimi et al., 2013).

Table 6. Relative contribution (partial and model $\mathrm{R}^{2}$ ), regression coefficient (b), standard error (SE), t-value and probability value (P) in predicting safflower oil yield by the stepwise procedure analysis

\begin{tabular}{llllllll}
\hline Step & Variable entered & Partial $\mathbf{R}^{\mathbf{2}}$ & Model $\mathbf{R}^{\mathbf{2}}$ & $\mathbf{b}$ & SE & t & P-value \\
\hline 1 & SY & 0.818 & 0.818 & 0.292 & 0.0033 & 87.33 & 0.000 \\
2 & OC & 0.179 & 0.997 & 1.397 & 0.0325 & 43 & 0.000 \\
\hline
\end{tabular}

RSquare: 0.9970; RSquare Adj: 0.9968

Path analysis is effective and convenient method for explaining dependent variable and explains well degrees of direct and indirect effect of yield components on yield (Topal et al., 2004). Table 7 showed that seed yield (0.9311), oil content (0.3653), plant height (0.0076), number of branch per plant $(0.0025)$, number of head per plant (0.0015), head diameter (0.0096), seed weight (0.0086), exerted positive direct effect on oil yield. This result indicated that a slight increase in terms of these characters may directly contribute to oil yield. Meanwhile the highest indirect effect percentage of number of head per plant (97.17) followed by number of branches per plant (91.67), plant height (73.80), seed weight (68.33) was found via seed yield. According to these results; studied characters, except of head diameter, important selection criterion to obtain higher oil yield genotype in spring safflower, Gencer et al. (1987) determined that plant height and seed weight; Patil (1998) seed weight, number of head and branch per plant; Tuncturk and Ciftci (2004) number of head per plant and seed per head; Arslan (2007) head diameter, number of head per plant and number of seed per head had positive direct effect on seed yield. Whereas, Omidi (2000) revealed that number of head per plant had positive direct effect, Mahasi et al. (2006) reported negative direct effect on seed yield. A study conducted rainfed condition, it has been reported that seed weight has a positive direct effect on oil yield (Katar, 2013). It was determined that differences and similarities between the results of the previous studies and this research as a result of the environmental and genotypic differences.

According to principal component analyze results, variable could be grouped in two components and these components account for $65.4 \%$ of the total variation of oil yield. The first PC contributed $44.17 \%$ of the overall variance of the studied characters, the second PC $20.87 \%$ on seed yield, seed weight, number of branch per plant, number of head per plant and oil content (Table 8, Figure 1). These results implied that seed yield, oil content and seed weight showed up to be important characters for oil yield of spring safflower. Studies revealed that correlation between oil yield and seed yield, seed weight, number of branch per plant, number of head per plant and oil content. Mozaffari and Asadi (2006) were observed that for the first principal component plant height, head diameter, oil content had positive correlation between them. A study was conducted to 30 spring safflower genotype by Ahmadzadeh (2013) found that three principal components with eigenvalue more than one which contributed 72.92 present of the total variability. Determination the effective plant characters will play important role to increase breeding programs in which success in it highly depends on straightness and effectiveness of yield components (Katar, 2013). 
Table 7. Path coefficient (direct and indirect effects) analysis of studied characters on oil yield in safflower over the three years

\begin{tabular}{cccccccc}
\hline $\begin{array}{c}\text { Path coefficient } \\
\text { Percentage (\%) }\end{array}$ & SY & OC & PH & NBPP & NHPP & HD & SW \\
\hline SY & $\mathbf{0 . 9 3 1 1}$ & -0.0086 & 0.0008 & 0.0008 & 0.0006 & 0.0005 & 0.0019 \\
& $\mathbf{9 8 . 5 9}$ & 0.91 & 0.08 & 0.08 & 0.06 & 0.05 & 0.20 \\
OC & -0.020 & $\mathbf{0 . 3 6 5 3}$ & 0.0050 & 0.0001 & 0.0001 & -0.0018 & 0.0020 \\
& 5.62 & $\mathbf{9 3 . 2 6}$ & 0.12 & 0.02 & 0.01 & 0.45 & 0.51 \\
PH & 0.1004 & 0.0222 & $\mathbf{0 . 0 0 7 6}$ & 0.0010 & 0.0004 & -0.0039 & -0.0006 \\
& 73.80 & 16.33 & $\mathbf{5 . 5 7}$ & 0.73 & 0.26 & 2.88 & 0.41 \\
NBPP & 0.3069 & 0.0167 & 0.0030 & $\mathbf{0 . 0 0 2 5}$ & 0.0012 & -0.0043 & 0.0002 \\
& 91.67 & 4.97 & 0.90 & $\mathbf{0 . 7 4}$ & 0.36 & 1.29 & 0.04 \\
NHPP & 0.3828 & -0.0012 & 0.0018 & 0.0020 & $\mathbf{0 . 0 0 1 5}$ & -0.0035 & 0.0011 \\
& 97.17 & 0.29 & 0.46 & 0.51 & $\mathbf{0 . 3 9}$ & 0.89 & 0.28 \\
HD & 0.0488 & -0.0682 & -0.0031 & -0.0011 & -0.0006 & $\mathbf{0 . 0 0 9 6}$ & 0.0004 \\
& 37.05 & 51.72 & 2.35 & 0.85 & 0.42 & $\mathbf{7 . 2 7}$ & 0.32 \\
SW & 0.2046 & 0.0850 & -0.0005 & 0.0001 & 0.0002 & 0.0005 & $\mathbf{0 . 0 0 8 6}$ \\
& 68.33 & 28.37 & 0.16 & 0.02 & 0.06 & 0.16 & $\mathbf{2 . 8 8}$ \\
\hline
\end{tabular}

Bold figures denotes direct effects while regular figures denote indirect effects

Table 8. Principal components of spring safflower genotype

\begin{tabular}{lcc}
\hline \multicolumn{1}{c}{ Traits } & PC1 & PC2 \\
\hline Percent of variance & 44.17 & 20.87 \\
Cumulative variance & 44.17 & 65.04 \\
\hline \multicolumn{3}{c}{ Eigenvectors } \\
\hline Seed yield & 0.388 & 0.357 \\
Oil content & 0.223 & 0.222 \\
Number of branch per plant & 0.420 & -0.392 \\
Number of head per plant & 0.427 & -0.377 \\
Plant height & -0.321 & 0.292 \\
Head diameter & -0.106 & 0.442 \\
Seed weight & 0.374 & 0.267 \\
\hline
\end{tabular}

Cluster I includes plant height and seed yield while head diameter and number of branches per plant belonged to Cluster II (Figure 2). Cluster III consisted of seed weight, number of head per plant, oil yield and content. These results revealed that, seed weight, number of head per plant and oil content could be regarded as important characters for high oil yielding genotypes in spring safflower breeding programs. A research was conducted to 5 spring safflower genotype by Katar (2013) showed seed weight, oil content and seed yield per plant as important characters to obtained high oil yielding safflower genotypes in cluster analysis.

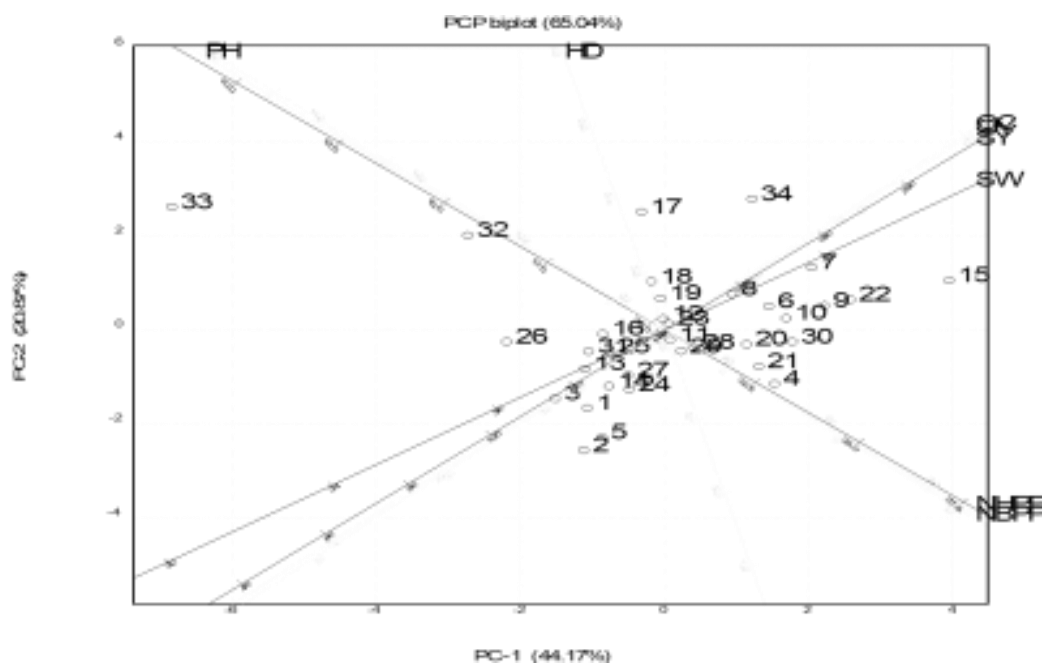

Figure 1. Scatter diagram of spring safflower genotype and studied characters 


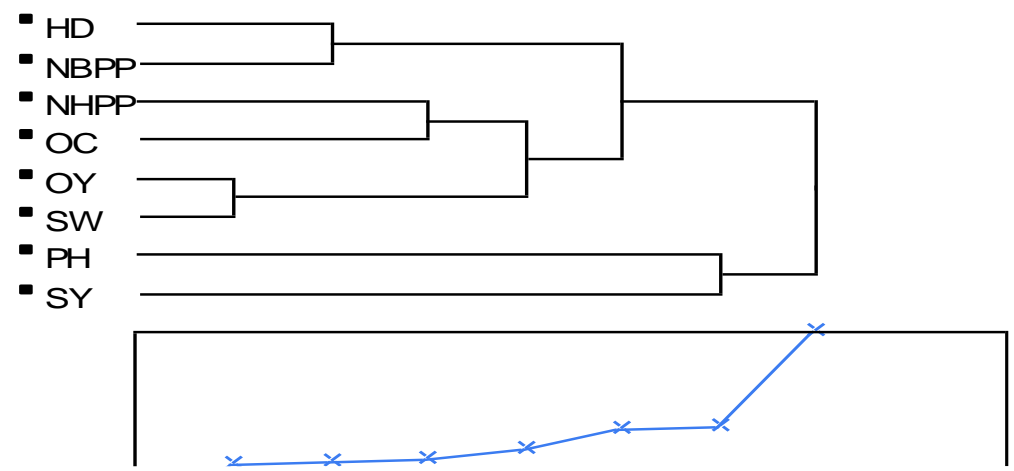

Figure 2. Cluster of characters having different distance levels

According to the results of statistical analyses essential variables effective on oil yield in spring safflower in this study are given Table 9. According to the multiple statistical procedures used in this research revealed that the selection based on oil content, seed weight, seed yield and number of head per plant this material would probably the most useful characters for increasing oil yield in spring safflower. The result of present study could be exploited in planning and execution of future breeding program in spring safflower.

Table 9. Results of statistical analyses indicating effective characters on oil yield in spring safflower

\begin{tabular}{ccccccc}
\hline Characters & $\mathbf{1}$ & $\mathbf{2}$ & $\mathbf{3}$ & $\mathbf{4}$ & $\mathbf{5}$ & $\mathbf{6}$ \\
\hline SY & $\mathrm{X}$ & $\mathrm{X}$ & $\mathrm{X}$ & $\mathrm{X}$ & $\mathrm{X}$ & \\
\hline OC & $\mathrm{X}$ & $\mathrm{X}$ & $\mathrm{X}$ & $\mathrm{X}$ & $\mathrm{X}$ & $\mathrm{X}$ \\
\hline PH & $\mathrm{X}$ & $\mathrm{X}$ & & $\mathrm{X}$ & & \\
\hline NBPP & $\mathrm{X}$ & $\mathrm{X}$ & & $\mathrm{X}$ & & \\
\hline NHPP & $\mathrm{X}$ & $\mathrm{X}$ & & $\mathrm{X}$ & & $\mathrm{X}$ \\
\hline HD & & & & & & \\
\hline SW & $\mathrm{X}$ & $\mathrm{X}$ & & $\mathrm{X}$ & $\mathrm{X}$ & $\mathrm{X}$
\end{tabular}

1: Correlation analysis 2: Multiple linear regression analysis 3: Stepwise analysis, 4: Path analysis 5: Principal component analysis 6: Cluster analysis.

\section{LITERATURE CITED}

Afroz, R., M. S. H. Sharif and L. Rahman. 2004. Genetic variability, correlation and path analysis in mustard and rape (Brassica spp.). Bangladesh J. P1ant. Breed. Genet.17:59-63.

Ahmadzadeh, A.R. 2013. Genetic diversity and classification of spring safflower (Carthamus tinctorius) cultivars using morphological characters. Advances in Bio. Research Adv. 4:125-131.

Arslan, B. 2007. The path analysis of yield and its components in safflower (Carthamus tinctorius L.). J. of Bio. Sci. 7:668-672.

Behnam, T., A. Said, S. Mohamadreza, B. B. Alireza and G. Gafari. 2011. Path analysis of seed and oil yield in safflower (Carthamus tinctorius L.). Int. J. Agric. Crop. Sci. 3:114-122.

Bidgoli, A.M., G.A. Akbari, M.J. Mirhadi, E. Zand and S. Soufizadeh. 2006. Path analysis of the relationships between seed yield and some morphological and phonological traits in safflower (Carthamus tinctorius L.). Euphytica 148:261-268.

Camas, N., A.K. Ayan and C. Cirak. 2005. Relationships between seed yield and some characters of Safflower (Carthamus tinctorius L.) cultivars grown in the middle black sea conditions. VI ${ }^{\text {th }}$ Int. Safflower Conference. 06-10 June 2005. Istanbul.
Camas, N. and Esendal, E. 2006.Estimates of broad-sense heritability for seed yield and yield components of safflower (Carthamus tinctorius L.). Hereditas 143:55-57.

Gencer, O., S.N. Sinan and F. Gulyasar. 1987. Relationship between oil and traits using correlation and path coefficient analysis in safflower. J. Agric. Faculty 2:37-43.

Golkar, P., A. Arzani and A.M. Rezaei. 2011. Determining relationships among seed yield, yield components and morpho-phenological traits using multivariate analyses in safflower (Carthamus tinctorious L.). Annals of Bio. Research 2:162-69.

Golparvar, A.R. 2011a. Assessment of relationship between seed and oil yield with agronomic traits in spring safflower cultivars under drought stress condition. J. Res. Agric. Sci. 7:109-113.

Golparvar, A.R. 2011b. Genetic improvement of oil yield in spring safflower cultivars under drought and non-drought stress conditions. Electronic J. of Biology 7:40-43.

Hannachi, A., Z. Fellahi, H. Bouzerzour and A. Boutekrabt. 2013. Correlation, path analysis and stepwise regression in durum wheat (Triticum Durum Desf.) under rainfed conditions. J. of Agric. and Sustainability 3:122-131.

Hussain, T., M.A. Tariq, I. Ahmad, M. Saghir, M. Batool, M. Safdar and M. Tariq. 2014. Characters association analysis in Safflower (Carthamus tinctorius L.). J. of Biology, Agric. and Healthcare 4:63-65.

Karimi, M., A.R. Golparvar and M. Shams. 2013. Multivariate regression and path coefficient analysis of seed and oil yield in spring safflower (Carthamus tinctorius L.) cultivars. App. Sci. Report 4:184-186.

Katar, D. 2013. Determination of efficiency of yield components on oil yield per plant in safflower breeding by different statistical methods. Global J. of Sci. Frontier Res. Agric. and Veterinary 13:11-20.

Khan, N. and F.N. Naqvi. 2012. Correlation and path coefficient analysis in wheat genotypes under irrigated and non-irrigated conditions. Asian J. of Agric. Sci. 4:346-351.

Khan, A.A., M.A. Alam, M.K. Alam, M.J. Alam and Z.I. Sarker. 2013. Correlation and path analysis of durum wheat (Triticum Turgidum L. Var. Durum). Bangladesh J. Agril. Res. 38:515521.

Laei, G., H. Afshari, M.R.J. Kamali and A.A. Hassanzadeh. 2012. Study yield and yield components comparison correlation some physiological characteristics. 20 genotypes of bread wheat. Annals of Bio. Res. 3: 4343-435.

Mahasi, M.J., R.S. Pathak, F.N. Wachira, T.C. Riungu, M.G. Kinyua and J.W. Kamundia. 2006. Correlations and path coefficient analysis in exotic safflower (Carthamus tinctorius L.) genotypes tested in the arid and semi-arid lands (Asals) of Kenya. Asian J. of Plant Sci. 5:1035-1038. 
Mozaffari, K. and A.A. Asadi. 2006. Relationship among traits using correlation, principal component and path analysis in safflower mutants in irrigated and drought stress condition. Asian J. of Plant Sci. 5:977-983.

Omidi, T.A.H. 2000. Correlation between traits and path analysis for grain and oil yield in spring safflower. Sesame and Safflower Newsletter 15:78-83.

Ozturk, O. 1994. Investigation on yield and yield components of some safflower cultivars under Konya ecological conditions, MS Thesis, Selcuk Univ., Grad. School of Nat. Sci. Dep. of Agronomy. $69 \mathrm{p}$

Patil, B.R., S.G. Deshmukh and M.P. Deshmukh. 1990. Studies on correlation and path analysis in safflower. Annals of Plant Physiology 4:86-91.

Patil, H.S., 1998. Genetic variability, association and path analysis in safflower. Indian J. Agric. Res. 32:46-50.

Samonte, S.O., L.T. Wilson and A. Mc Clung. 1998. Path analysis of yield and yield-related traits of fifteen diverse rice genotypes. Crop Sci. 38:1130- 1136.

Slavkovic, L., B. Skrbic, N. Miljevic and A. Onjia. 2004. Principal component analysis of trace elements in industrial soils. Environ. Chemistry Letters 2:105-108.
Tonk, F. A., E. İlker and M. Tosun. 2011. Quantative inheritance of some wheat agronomic traits. Bulgarian J. of Agric. Sci.17:783-788

Topal, M., M. Ozdemir, V. Aksakal, N. Yildiz and U. Dogru. 2004. Determination of the best nonlinear function in order to estimate growth in Morkaraman and Awassi lambs, Small Rumin Res. 55:229-232.

Topal, M., E. Ozturk and T. Polat. 2010. Path analysis of seed yield components using different correlation coefficients in safflower (Carthamus tinctorius L.). The J. of Animal and Plant Sci. 20:220-224.

Tuncturk, M. and V. Ciftci. 2004. Relationships among traits using correlation and path coefficients analysis in safflower (Carthamus tinctorius L.) sown different fertilization levels and row spacing. Asian J. of Plant Sci. 3:683-686.

Zafarnaderi, N, S. Aharizad and S.A. Mohammadi. 2013. Relationship between grain yield and related agronomic traits in bread wheat recombinant inbred lines underwater deficit condition. Annals of Bio. Res. 4:7-11. 